\title{
Identification of snow ablation rate, ELA, AAR and net mass balance using transient snowline variations on two Arctic glaciers
}

\author{
Sebastian H. MERNILD, ${ }^{1,2}$ Mauri PELTO, ${ }^{3}$ Jeppe K. MALMROS, ${ }^{2}$ Jacob C. YDE, ${ }^{4}$ \\ Niels T. KNUDSEN, ${ }^{5}$ Edward HANNA ${ }^{6}$ \\ ${ }^{1}$ Climate, Ocean, and Sea Ice Modeling Group, Los Alamos National Laboratory, Los Alamos, NM, USA \\ ${ }^{2}$ Glaciology and Climate Change Laboratory, Center for Scientific Studies/Centro de Estudios Científicos (CECS), \\ Valdivia, Chile \\ E-mail: mernild@cecs.cl \\ ${ }^{3}$ Department of Environmental Science, Nichols College, Dudley, MA, USA \\ ${ }^{4}$ Sogn og Fjordane University College, Sogndal, Norway \\ ${ }^{5}$ Department of Geoscience, University of Aarhus, Aarhus, Denmark \\ ${ }^{6}$ Department of Geography, University of Sheffield, Sheffield, UK
}

\begin{abstract}
Identification of the transient snowline (TSL) from high spatial resolution Landsat imagery on Lemon Creek Glacier (LCG), southeast Alaska, USA, and Mittivakkat Gletscher (MG), southeast Greenland, is used to determine snow ablation rates, the equilibrium-line altitude (ELA) and the accumulation-area ratio (AAR). The rate of rise of the TSL during the ablation season on a glacier where the balance gradient is known provides a measure of the snow ablation rate. On both LCG and MG, snow pits were completed in regions that the TSL subsequently transects. This further provides a direct measure of the snow ablation rates for a particular year. TSL observations from multiple dates during the ablation season from 1998 to 2011 at LCG and 1999 to 2012 at MG were used to explore the consistency of the TSL rise and snow ablation rate. On LCG and MG the satellite-derived mean TSL migration rates were $3.8 \pm 0.6$ and $9.4 \pm 9.1 \mathrm{~m} \mathrm{~d}^{-1}$, respectively. The snow ablation rates were $0.028 \pm 0.004 \mathrm{~m}$ w.e. $\mathrm{d}^{-1}$ for LCG and $0.051 \pm 0.018 \mathrm{mw}$ w.e $\mathrm{d}^{-1}$ for MG estimated by applying a TSLmass-balance-gradient method, and $0.031 \pm 0.004$ and $0.047 \pm 0.019 \mathrm{~m}$ w.e. $\mathrm{d}^{-1}$ by applying a snow-pitsatellite method, illustrating significant agreement between the two different approaches for both field sites. Also, satellite-derived ELA and AAR, and estimated net mass-balance $\left(B_{\mathrm{a}}\right)$ conditions were in agreement with observed ELA, AAR and $B_{a}$ conditions for LCG and MG.
\end{abstract}

\section{INTRODUCTION}

There is a strong relationship between annual glacier equilibrium-line altitude (ELA; the ELA is the spatially averaged elevation of the equilibrium line, defined as the set of points on the glacier surface where the annual net mass balance is zero) and net mass balance $\left(B_{\mathrm{a}}\right)$, and between accumulation-area ratio (AAR: the ratio of the accumulation area to the area of the entire glacier) and $B_{\mathrm{a}}$ (Dyurgerov, 1996; Hock and others, 2007). For instance, the World Glacier Monitoring Service produces detailed graphs showing the coupling between $B_{\mathrm{a}}$ and both ELA and AAR on a global scale (WGMS, 2011). Remote-sensing imagery provides a useful tool for identifying the ELA and transient snowline (TSL) in areas where field observations are lacking or on regional scales (Østrem, 1975). The TSL is the location of the transition from snow cover to, for example, bare glacier ice, superimposed ice and firn at a particular time during the ablation season (Østrem, 1975), whereas the ELA is the altitude of the snowline at the end of the ablation season. The transient mass balance (defined as the glacier mass balance from the onset of the accumulation season to a particular time in the following ablation season, and assuming that the specific winter mass balance is not negative anywhere on the glacier) at the TSL is zero (Hock and others, 2007), providing an important reference point for constructing a balance gradient curve. The TSL can be identified near the end of the ablation season using aerial photographs or satellite imagery (Hall and others, 1989). However, in many years the time-span between available and usable imagery where the TSL is visible at the end of the ablation season can be several weeks. If the migration rate of TSL can be determined along a balance gradient curve and is reasonably consistent, the ELA can be reliably estimated from TSL observations conducted several weeks before the end of the melt season (Pelto, 2011). Observations of TSL from the early part of the ablation season should be excluded from the balance gradient curve because the entire glacier will remain snowcovered (transient $\mathrm{AAR}=1$ ) until the TSL becomes visible when all snow has melted at one point on the glacier (Hock and others, 2007). The current availability of satellite imagery from many sources ensures coverage late in the ablation season for the most recent years since the early 1990s. Once the AAR- $B_{\text {a }}$ relation is calibrated for a particular glacier, the approach outlined above using TSL-AAR and TSL-ELA observations enables accurate remote monitoring of glacier net mass balance. This is important since glaciers are climate-sensitive, and for understanding and predicting glacier response during climate warming related to, for example, watershed hydrology and global sea-level rise.

Here we explore the capability of satellite imagery to: (1) determine the TSL migration rates throughout the ablation season for two individual glaciers - Lemon Creek Glacier, southeast Alaska, USA (Fig. 1a), and Mittivakkat Gletscher, southeast Greenland (Fig. 1b) - in two different 


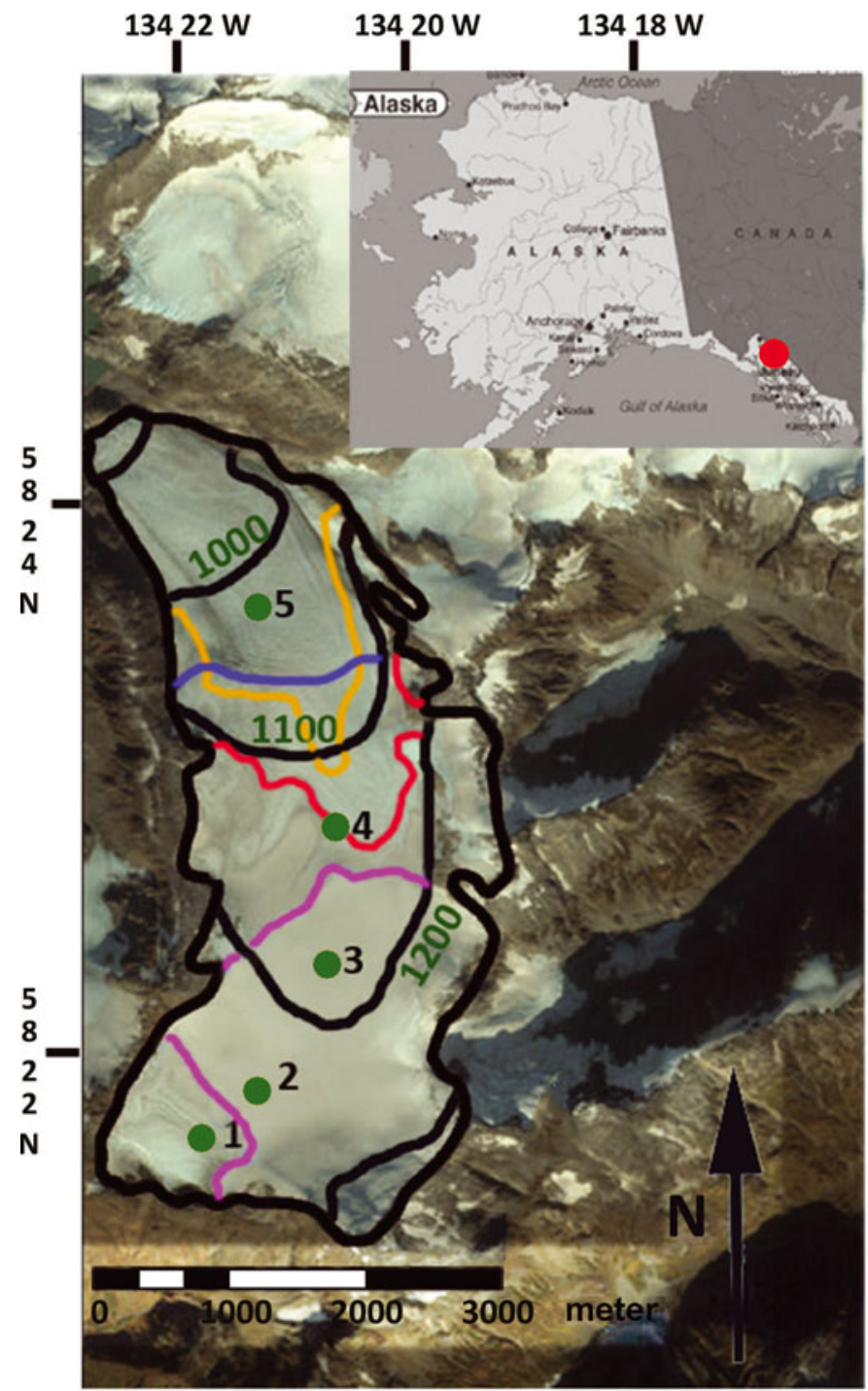

Lemon Creek 1999

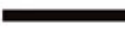

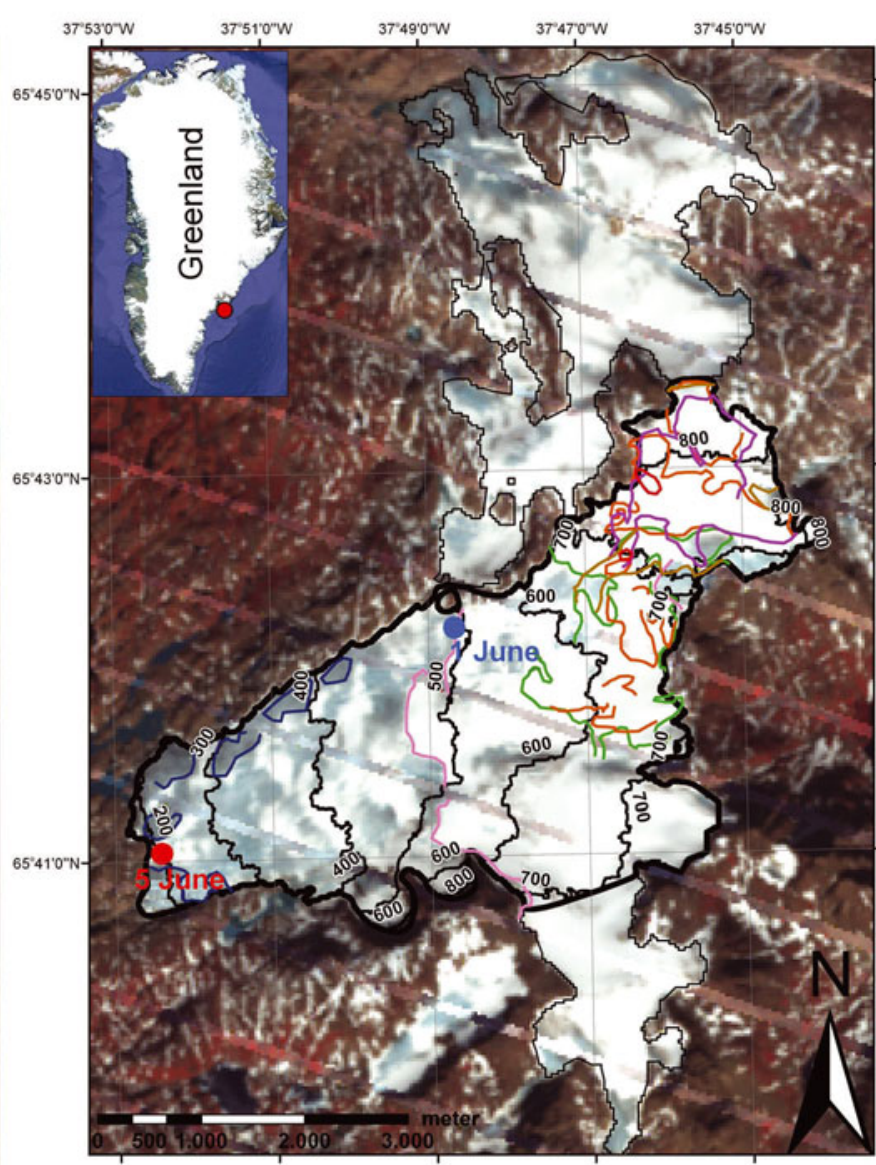

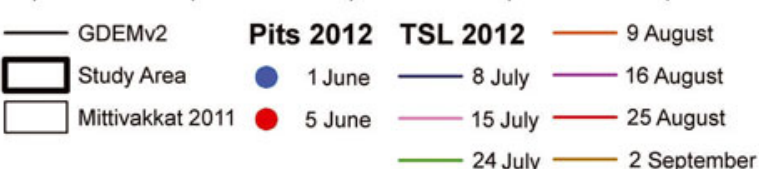

b

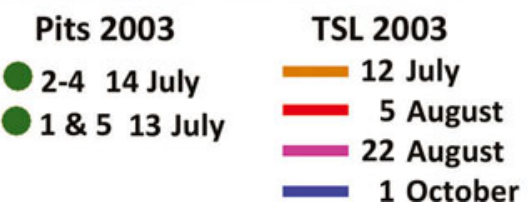

Fig. 1. (a) Satellite image of Lemon Creek Glacier $\left(11.6 \mathrm{~km}^{2}\right)$ (inset indicates general location of the glacier in southeastern Alaska), with $100 \mathrm{~m}$ contour intervals. Green dots (1-5) indicate standard snow-pit locations from 2003, and colored bold lines the seasonal locations of snowlines during the 2003 ablation season. The glacier boundary is for 1999 and estimated from Global Land Ice Measurements from Space (GLIMS; www.glims.org). (b) Satellite image of Mittivakkat Gletscher $\left(26.2 \mathrm{~km}^{2}\right.$ in total in 2011, and $15.9 \mathrm{~km}{ }^{2}$ for the observed $B_{\text {a }}$ study area) (inset indicates general location of the glacier in southeast Greenland), with $100 \mathrm{~m}$ contour intervals. The red and the blue dots indicate an example of snow-pit locations from 2012, and the colored bold lines the seasonal locations of snowlines during the 2012 ablation season. The glacier boundary is based on Landsat 7 ETM+ Mosaic imagery (1 August 2009 and 14 August 2011 ).

Arctic climate settings; (2) estimate snow ablation rates; (3) reconstruct elevation of the ELA based on the TSL-ELA relation; (4) estimate AAR conditions; (5) reconstruct observed $B_{\mathrm{a}}$ based on a satellite-derived $\mathrm{AAR}-B_{\mathrm{a}}$ relation; and (6) estimate the out-of-equilibrium conditions with the present-day climate. At both glaciers, detailed $B_{\text {a }}$ measurements have been conducted for many years (Miller and Pelto, 1999; WGMS, 2011; Mernild and others, 2012). These data, including the mass-balance gradients and the TSL migration rate (henceforth the TSL-mass-balance-gradient method), have been validated by snow ablation rates calculated from snow-pit data (henceforth the snow-pitsatellite method) (see Section 3).

\section{STUDY AREAS}

\section{Lemon Creek Glacier}

Lemon Creek Glacier (LCG; $11.6 \mathrm{~km}^{2} ; 58^{\circ} 23^{\prime} \mathrm{N}, 134^{\circ} 24^{\prime} \mathrm{W}$ ) is located in the Juneau Icefield in the Coast Range of southeast Alaska (Fig. 1a), and is a temperate valley glacier (Marcus and others, 1995). The $B_{a}$ of the LCG has been monitored since 1953 by the Juneau Icefield Research Program (JIRP) (Pelto and Miller, 1990). LCG extends from 820 to $1400 \mathrm{~m}$ a.s.l. From the head of the glacier to the mean ELA at 1050-1100 ma.s.I. (1998-2010) (WGMS, 2011) (annual variations in ELA are illustrated in Fig. 2a), the glacier flows northward, and in the ablation zone it turns 

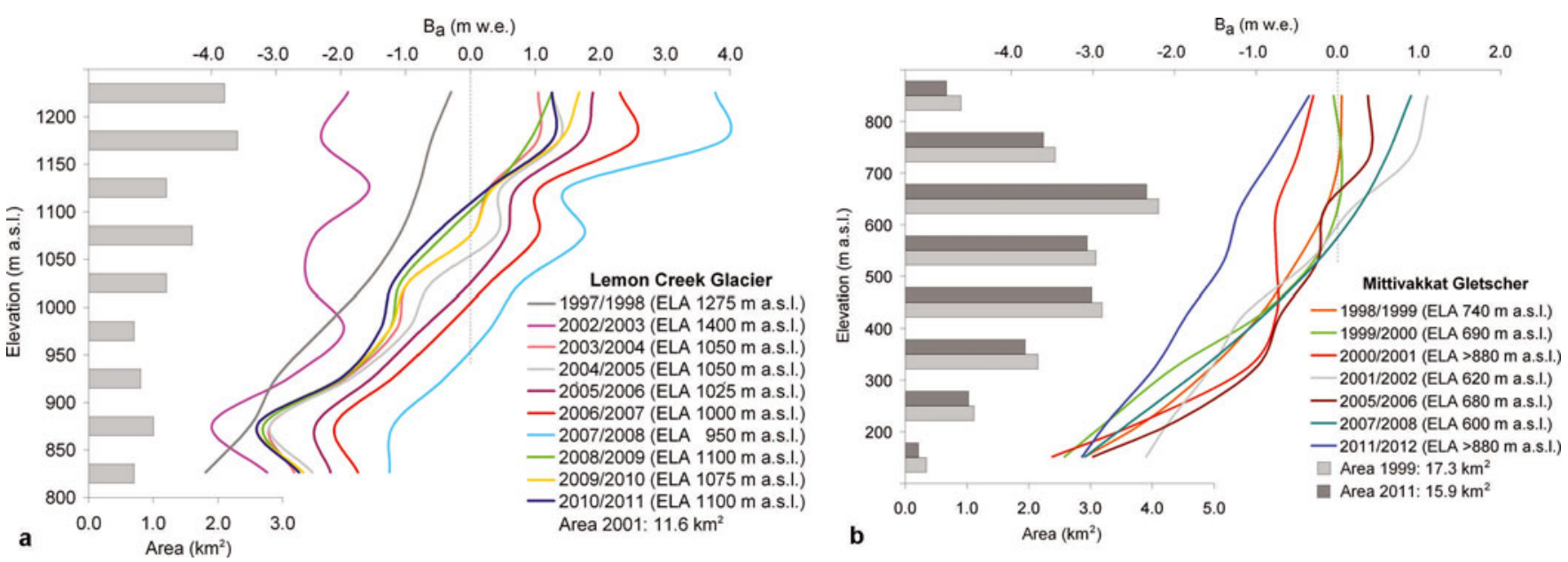

Fig. 2. (a) Area elevation band distribution for 2001 derived from Landsat ETM+ Mosaic and observed balance gradients of LCG for $1997 / 98$, 2002/03, 2003/04, 2004/05, 2005/06, 2006/07, 2007/08, 2008/09, 2009/10 and 2010/11, the same years when Landsat TM imagery was obtained to estimate TSL trends (Table 2). (b) Area elevation band distribution for 1999 and 2011 derived from Landsat 7 ETM+ Mosaic and observed balance gradients of MG for 1998/99, 1999/2000, 2000/01, 2001/02, 2005/06, 2007/08 and 2011/12, the same years when Landsat TM/ETM+ imagery was obtained to estimate TSL trends (Table 3).

westward, terminating at $\sim 820$ ma.s.I. LCG surface slope changes from $\sim 4^{\circ}$ in the accumulation area to $\sim 18^{\circ}$ at the termini. The glacier terminus retreated on average 10$13 \mathrm{~m} \mathrm{a}^{-1}$ between 1998 and 2009. For LCG the observed $B_{\mathrm{a}}$ was on average -0.44 mw.e. $\mathrm{a}^{-1}$ from 1953 to 2011 and $-0.51{\mathrm{~m} w . e . \mathrm{a}^{-1}}$ from 1996 to 2011 (Pelto and Miller, 1990; WGMS, 2011); winter and summer balances are not determined separately. LCG is located in a sub-Arctic region of temperate maritime climate, with annual precipitation of $\sim 3000-4000 \mathrm{~mm}$ and an average annual air temperature at the ELA of $-1{ }^{\circ} \mathrm{C}$.

\section{Mittivakkat Gletscher}

Mittivakkat Gletscher (MG; $26.2 \mathrm{~km}^{2}$ in $2011 ; 65^{\circ} 41^{\prime} \mathrm{N}$, $37^{\circ} 48^{\prime} \mathrm{W}$ ) is located in the Ammassalik region, southeast Greenland (Fig. 1b), and is a temperate glacier (Knudsen and Hasholt, 1999). It extends from 160 to 880 ma.s.I. Since the end of the Little Ice Age around AD 1900, MG has undergone almost continuous retreat (Knudsen and others, 2008; Mernild and others, 2011a), in which the glacier area decreased by 18\% (1986-2011) (Mernild and others, 2012), volume decreased by 30\% (1986-2011) (Mernild and others, 2013) and the mean surface slope increased from $0.095 \mathrm{~m} \mathrm{~m}^{-1}\left(=5.4^{\circ}\right)$ to $0.104 \mathrm{~m} \mathrm{~m}^{-1}\left(5.9^{\circ}\right)(1986-2011)$.

For MG the $B_{\mathrm{a}}$ has been observed for 17 years since 1995/ 96 , and the winter and summer balances individually for only 11 years ( $B_{\mathrm{a}}$ was measured over the study area: $17.3 \mathrm{~km}^{2}$ in 1999 and $15.9 \mathrm{~km}^{2}$ in 2011). $B_{\mathrm{a}}$ is $-1.01 \pm 0.74 \mathrm{~m}$ w.e. $\mathrm{a}^{-1}$ (1995/96 to 2011/12), with a mean winter balance of $1.16 \pm 0.20 \mathrm{mw} . e . \mathrm{a}^{-1}$ and a mean summer balance of $-1.99 \pm 0.40 \mathrm{~m}$ w.e. $\mathrm{a}^{-1} \quad(1995 / 96$ to $2001 / 02,2004 / 05$ to 2005/06, 2007/08 and 2011/12). In 2010/11, $B_{\text {a }}$ was at a record setting, $-2.45 \mathrm{~m}$ w.e.: about two standard deviations below the mean, and $0.29 \mathrm{~m}$ w.e. more negative than the previous observed record low $B_{\mathrm{a}}$ in 2009/10 (Mernild and others, 2011b). The loss of $1.63 \mathrm{~m}$ w.e. in $2011 / 12$ was the fourth highest loss since 1995, and three of the four highest recorded $B_{\mathrm{a}}$ losses have occurred in the last three years included in this study. Since 1995, the mean ELA has risen from around $500 \mathrm{~m}$ a.s.l. to $750 \mathrm{~m}$ a.s.l. (Mernild and others, 2011a updated). Figure $2 \mathrm{~b}$ shows annual variations in ELA.
MG is considered to be located in the Low Arctic (Born and Böcher, 2001), and in a relatively wet and snowy part of Greenland (Mernild and Liston, 2010). An air temperature analysis reveals that the mean annual air temperature for MG was $-2.2^{\circ} \mathrm{C}(1993-2011)$ at $515 \mathrm{~m}$ a.s.l. (Mernild and others, 2008 updated), and a trend analysis of standard seasonal averages shows the following increases in seasonal air temperature for $1993-2011: 2.9^{\circ} \mathrm{C}$ in winter, $0.9^{\circ} \mathrm{C}$ in spring, $2.6^{\circ} \mathrm{C}$ in summer and $1.0^{\circ} \mathrm{C}$ in autumn (Hanna and others, 2012). The mean annual precipitation varied in the range $1400-1800 \mathrm{~mm}$ w.e. $\mathrm{a}^{-1}$ (1998-2006) (Mernild and others, 2008).

\section{METHODS}

For LCG and MG, respectively, imagery from the satellite platforms Landsat 5 Thematic Mapper (TM) and Landsat 7 Enhanced TM Plus (ETM+) was selected to estimate TSL migration rates, snow ablation rates, ELA and AAR. Below, specific details are illustrated for sensors, band information, scenes used in the analyses, and uncertainties related to the satellite imagery processing (Table 1).

\section{Satellite method at Lemon Creek Glacier}

The TSL on LCG is readily identifiable on 34 scenes acquired in 1998 and 2003-11, and visualized using the US Geological Survey (USGS) Globalization Viewer software (Table 1). LCG falls in path/row 58/19 and 57/19; all images are false-color RGB (red, green, blue) composites, bands 3, 4 and 5, with a $2 \%$ linear stretch applied. The $7.5 \mathrm{~min}$ quadrangle digital elevation model (DEM) from the United States Geological Survey was used (further information: http://eros.usgs.gov/\#/Guides/dem). The TSL is manually digitized for each scene. The exception is when the TSL rises to $1200 \mathrm{~m}$ a.s.l. or is $<900 \mathrm{~m}$ a.s.l.: in both cases the surface slopes increase, leading to higher error margins. The satellite images were georeferenced in ArcMap 9.3 using five topographically unique reference points. The five ground control points (GCPs) are part of the benchmark survey network for the Juneau Icefield; their position is determined in the field using rapid static and real-time GPS 
Table 1. Satellite platforms, sensors, band information and scenes used in the analysis related to the satellite study for Lemon Creek Glacier and Mittivakkat Gletscher

Lemon Creek Glacier Mittivakkat Gletscher M

Platforms

Sensors and bands

Ground resolution

Precision

Scenes (survey years and dates)*

Landsat 5 and 7
Landsat TM and ETM+ (bands 3 , 4 and 5)
土15 m (horizontal)
LT50580191998211PAC00
LT50580191998259PAC00
LT50580192003193PAC00
LE70580192003217EDC02
LT50570192003234PAC00
LE70570192003274EDC02
LE70570192004197EDC01
LT50570192004221PAC00
LE70570192004229EDC02
LT50570192004237PAC00
LE70570192004245EDC02
LE70570192004293EDC01
LE70580192005222EDC00
LE70570192005167EDC00
LT50570192006210PAC01
LT50570192006258PAC01
LE70580192006289EDC00
LE70580192007196EDC00
LE70580192007228EDC00
LT50570192007245PAC01
LT50570192007261PAC00
LT50570192007277PAC00
LT50570192008184PAC01
LT50570192008232PAC01
LE70570192009194EDC00
LE70580192009217SGS02
LT50580192009241PAC01
LT50580192009257PAC00
LT50570192010189PAC01
LT50580192010228GLC00
LT50580192010260GLC00
LT50580192010276GLC01
LT50570192011192PAC00
LE70580192011255EDC00
<+5-15 m (vertical)

Terra

Landsat TM and ETM+ (bands 2, 3 and 5) ASTER GDEM v2 $30 \mathrm{~m}, 15 \mathrm{~m}$ panchromatic

$\pm 15 \mathrm{~m}, 7.5 \mathrm{~m}$ panchromatic (horizontal) $\sim \pm 12.5 \mathrm{~m}$ (vertical)

LE72300141999211SGSO0

LE72310141999250AGSO0

LE72320141999193EDC00

LE72320141999241EDC00

LE72310142000173SGS00

LE72310142000253EDC00

LE72320142000228AGS00

epp232r014_7f20010701

LE72310142001271EDC00

LE72320142001182AGSO0

LE72320142001214AGSOO

LE72310142002210EDC00

LE72320142002217EDC00

LE72310142006205EDC00

LE72320132006244EDC00

LE72320142006180EDC00

LE72320142006244EDC00

LE72320142006260EDC00

LE72310142008227EDC00

LE72310142008275EDC00

LE72320142008170EDC00

LE72320142008202EDC00

LE72310142012190EDC00

LE72320142012197EDC00

LE72310142012206EDC00

LE72310142012222EDC00

LE72320142012229EDC00

LE72310142012238EDC00

LE72320142012245EDC00

*Information is inherent in the scene name, for example in LE70580192011255EDC00, with sensor LE7, path 058, row 019, year 2011, Julian day 255 and processing quality notes EDC00.

equipment with an accuracy of $0.01 \mathrm{~m}$ horizontally and $0.05 \mathrm{~m}$ vertically. The registration errors between the Landsat $5 \mathrm{TM}$ and $7 \mathrm{ETM}+$ products were $24 \mathrm{~m}$ root-mean-square error (RMSE) based on five GCPs. The image spatial resolution of $30 \mathrm{~m}$ and the registration of $24 \mathrm{~m}$ combined with mean surface gradients of $0.04-0.08 \mathrm{~m} \mathrm{~m}^{-1}$ yields an error of $\pm 1-4 \mathrm{~m}$ in TSL elevation, with a mean of $1.56 \mathrm{~m}$. The data frame containing imagery and base map was transformed to North American Datum (NAD) 1983, Universal Transverse Mercator (UTM) zone $8 \mathrm{~N}$ to ensure spatial accuracy for measurements.

\section{Satellite method at Mittivakkat Gletscher}

For MG the satellite imagery data were available through the USGS 'EarthExplorer' online database. The area of MG is covered by two Landsat overpasses path/row 231/14 and 232/14. The TSL on MG was identified using imagery from Landsat 5 TM and 7 ETM+ having a ground resolution of $30 \mathrm{~m}$ (Table 1). The TSL was manually digitized from the 26 scenes (Table 3, further below) by composing a false-color image from bands 2, 3 and 5, to maximize the snow-cover contrast in the image. A DEM was extracted from the Advanced Spaceborne Thermal Emission and Reflection Radiometer (ASTER) Global Digital Elevation Model Version 2 (GDEM v2), providing a vertical average precision of $\sim 12 \mathrm{~m}$ over Greenland (Tachikawa and others, 2011). The vertical error is expected to be closer to the GDEM v2 standard $\pm 8.7 \mathrm{~m}$ precision due to the gentle slope of the majority of the glacier from where the measurements were taken (Tachikawa and others, 2011). The lateral error associated with GDEM v2 is a little more than half a pixel $(17 \mathrm{~m})$. ASTER GDEM v2 is a product of the US Ministry of Economy, Trade, and Industry and NASA. The overall registration errors between the Landsat 5 TM and 7 ETM+ products were measured to be $21 \mathrm{~m}$ RMSE based on 31 GCPs (first order). The differences between ASTER GDEM v2 and Landsat 5 TM were $22 \mathrm{~m}$ RMSE based on 25 GCPs, and between ASTER GDEM v2 and Landsat 7 ETM+ were $20 \mathrm{~m}$ RMSE (23 GCPs). The vertical error produced by the registration errors was found to be $1.8-3.1 \mathrm{~m}$, averaging 

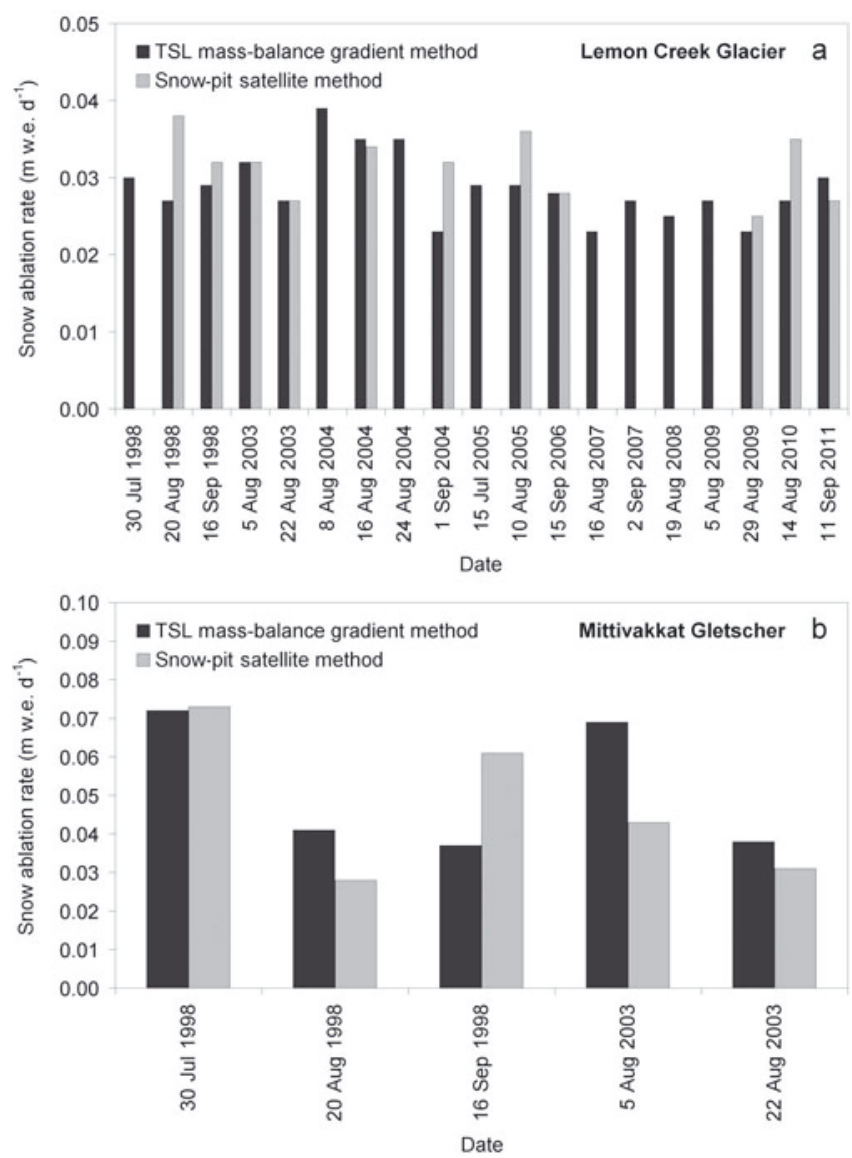

Fig. 3. Estimated snow ablation rates for LCG (a) and MG (b) based on the TSL-mass-balance-gradient method and the snow-pitsatellite method (Tables 2 and 3).

$2.2 \mathrm{~m}$, with a spatial resolution of $30 \mathrm{~m}$ and mean surface gradients of $0.06-0.10 \mathrm{~m} \mathrm{~m}^{-1}$. The data for MG were projected in World Geodetic System 1984 (WGS84), UTM zone $24 \mathrm{~N}$. The accuracy of the Landsat imagery was validated by in situ GPS measurements taken in the field from several years, and all measurements were within half a pixel (15 m) (Mernild and others, 2012).

\section{Calculations}

For LCG and MG the snow ablation rates were calculated based on both the TSL-mass-balance-gradient method and the snow-pit-satellite method (Fig. 3a and b). For the TSLmass-balance-gradient method snow ablation rates were calculated from the rise in TSL (Tables 2 and 3), where the TSL migration rates were multiplied with the field-determined balance gradients near the TSL. For the snow-pitsatellite method, the snow ablation rates were calculated based on observed snow loss in snow pits (Tables 2 and 3), where the snow depths were divided by the time interval for the TSL to transect the snow pits. For example, if the snowpack depth on 1 July in a snow pit was $1.4 \mathrm{~m}$ w.e., and on 12 August the TSL reached the snow pit, then it took 42 days to ablate $1.4 \mathrm{~m}$ w.e. of snow, yielding the snow ablation rate. At LCG, snow-pit excavations were conducted for the years 1998 and 2003-12 (Table 2) and at MG for the years 1999, 2000-02, 2006, 2008 and 2012 (Table 3).

The annual ELAs for LCG and MG were estimated based on second-order polynomial regression between the TSL elevation and the TSL date (remembering that for any specific date of TSL observation the transient mass balance at the TSL is zero), where ELA faces the highest calculated TSL at the end of the ablation season (Fig. 4a and b). In many years the time difference between available and usable imagery where the TSL is visible at the end of the ablation season can be several weeks, which is why the approach of utilizing a second-order polynomial regression is an advantage. The annual AAR was calculated from the estimated ELA. Both glaciers were partitioned into elevation bands (LCG $50 \mathrm{~m}$ elevation bands and MG $100 \mathrm{~m}$ elevation bands), and the AAR for a given observed year was determined based on the glacier area above and below the ELA: for LCG a fixed area of $11.6 \mathrm{~km}^{2}$ was used for the entire period, and for MG an assumed linearly decreasing area from $17.3 \mathrm{~km}^{2}$ (1999) to $15.9 \mathrm{~km}^{2}$ (2011) was used.

To reconstruct the LCG and MG $B_{\mathrm{a}}$, linear regressions between the estimated AAR and observed $B_{a}$ were used (for the entire MG the $B_{a}$ is considered to be accurate within $\sim 15 \%$ (Knudsen and Hasholt, 2004; Mernild and others, 2011a)). A linear regression between the AAR and $B_{a}$
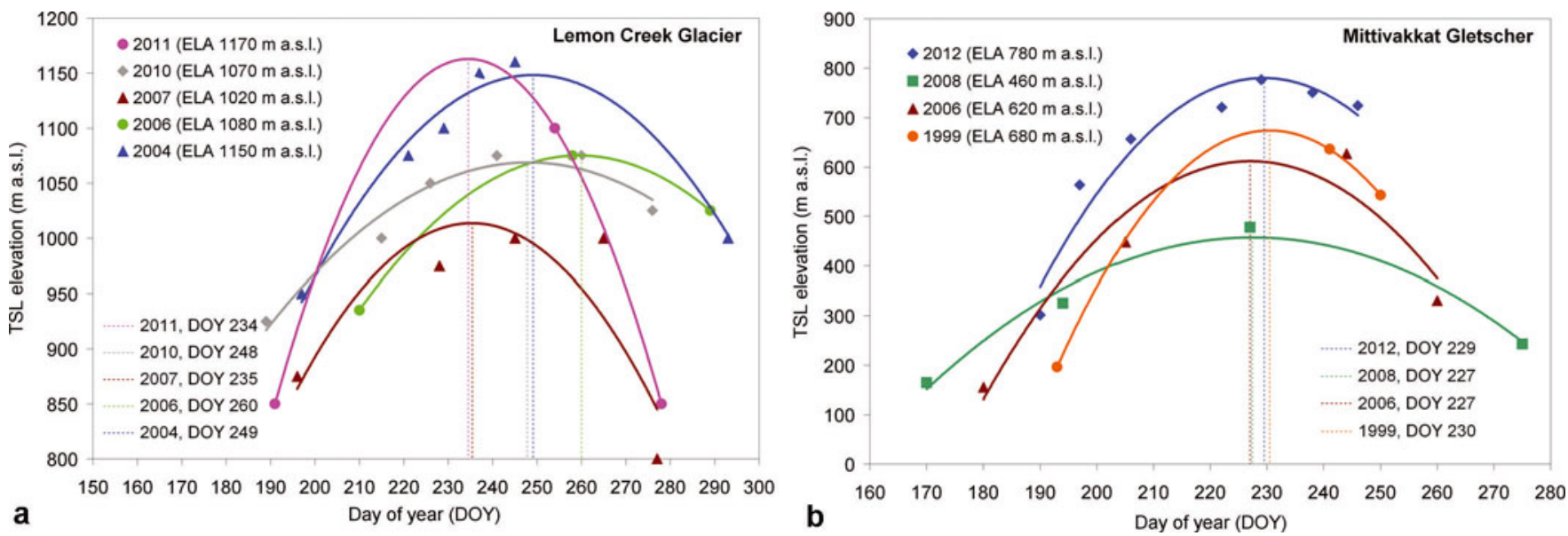

Fig. 4. (a) Satellite-derived LCG TSL elevations throughout five summer periods: 2004, 2006, 2007, 2010 and 2011. Only summer periods are shown from where TSL was estimated by satellite at least three times, including at the beginning of the accumulation season. The ELA is well estimated by TSL observations, except in 2011 when no observations occur within 15 days of the end of the melt season. (b) Satellitederived MG TSL elevations throughout four summer periods: 1999, 2006, 2008 and 2012. Only summer periods are shown from where TSL was estimated by satellite at least three times, including the beginning of the accumulation season. 
Table 2. Dates and elevation of TSL observations on LCG. The TSL elevation rate is the mean daily rise in TSL elevation since the previous observation date at least 15 days earlier. Snow-pit depth (SWE) is from the original mid-July excavation on the date indicated; the accumulated snow has completely ablated. Snow ablation rate is the ablation needed to remove the snow-pit accumulation by the observation date

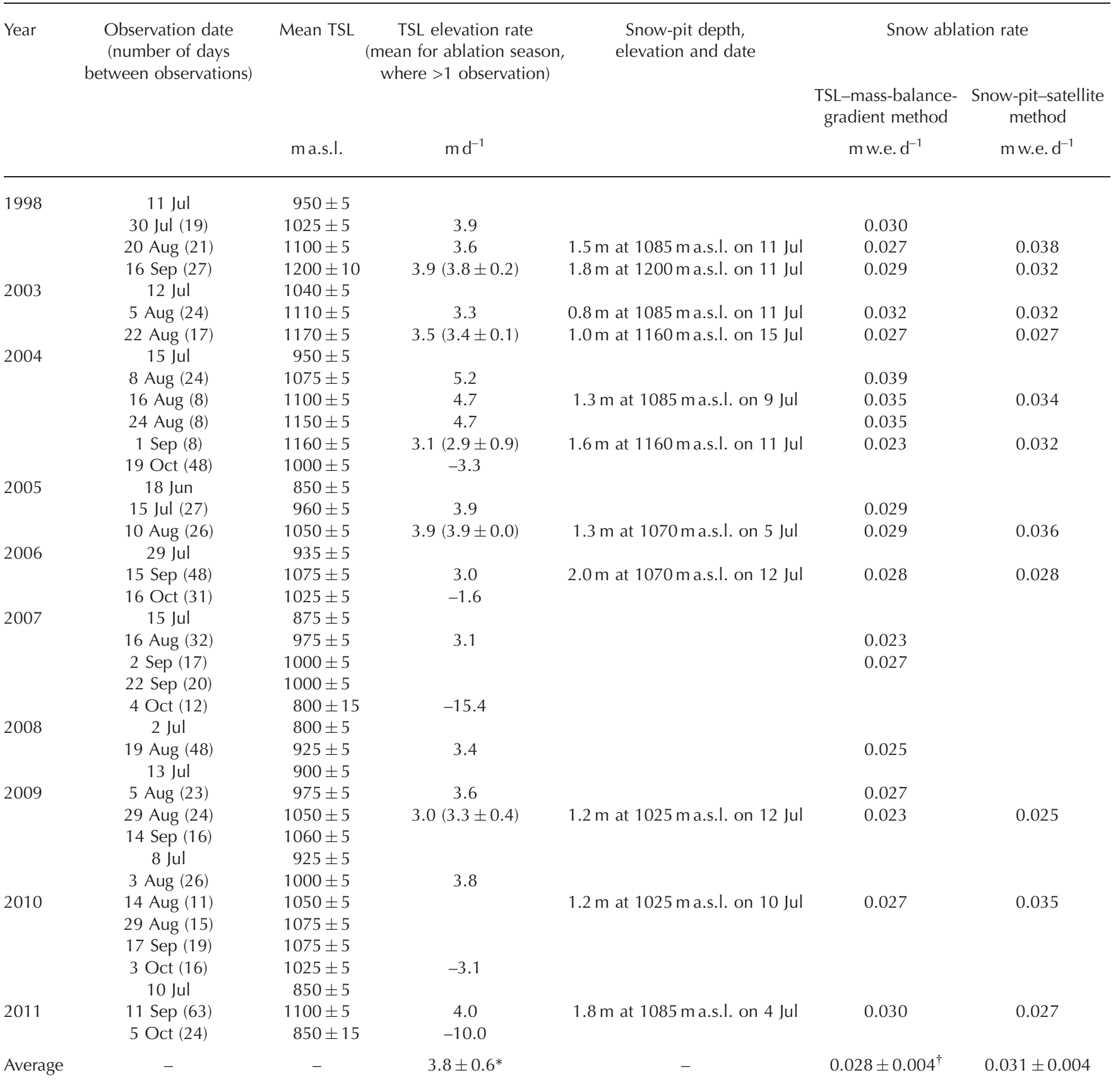

* Mean TSL elevation rate was calculated based on positive rates.

† Average and standard deviations were only calculated for years with data available from both glaciers.

gives the relation

$$
\mathrm{AAR}=s \cdot B_{\mathrm{a}}+\mathrm{AAR}_{0}
$$

where $s$ is the slope and $\mathrm{AAR}_{0}$ is the AAR when $B_{\mathrm{a}}=0$. Zero values of AAR were excluded from the regression (only MG experienced years where $A A R=0)$, since $A A R$ and $B_{a}$ are not linearly related when net ablation occurs all over the glacier surface (Mernild and others, 2011a). Additional information about the LCG $B_{\text {a }}$ program and methods is provided by Marcus and others (1995), Sapiano and others (1998) and Miller and Pelto (1999), and about the MG $B_{a}$ program by Knudsen and Hasholt (2008) and Mernild and others (2011a).

\section{RESULTS AND DISCUSSION}

\section{Snow ablation rates and ELA reconstruction}

The TSL for LCG was observed for 39 dates during the period that defines 25 time periods during which satellite observations are at least 15 days apart (Table 2). For MG the numbers were 25 dates within 11 time periods (Table 3). For LCG the observed positive TSL migration rates varied from $2.9 \pm 0.9 \mathrm{~m} \mathrm{~d}^{-1}$ (for the 2004 ablation season) to $3.9 \pm$ $0.0 \mathrm{~m} \mathrm{~d}^{-1}$ (2005) (having a migration rate of up to $5.2 \mathrm{~m} \mathrm{~d}^{-1}$ between subsequent satellite observations), with a mean for all ablation periods of $3.8 \pm 0.6 \mathrm{~m} \mathrm{~d}^{-1}$ (positive rates indicate when TSL is moving towards higher elevations, and, here 
Table 3. Dates, mean elevation and standard deviation of satellite-derived TSL on MG. Also shown are observed snow-pit and estimated snow ablation values. Where the TSL elevation rate is negative it indicates that the TSL has moved down-glacier. For the years 2000, 2001, 2002 and 2008, no snow ablation rates are estimated, either because of an insufficient number of snow pits or no available Landsat imagery for estimating TSL

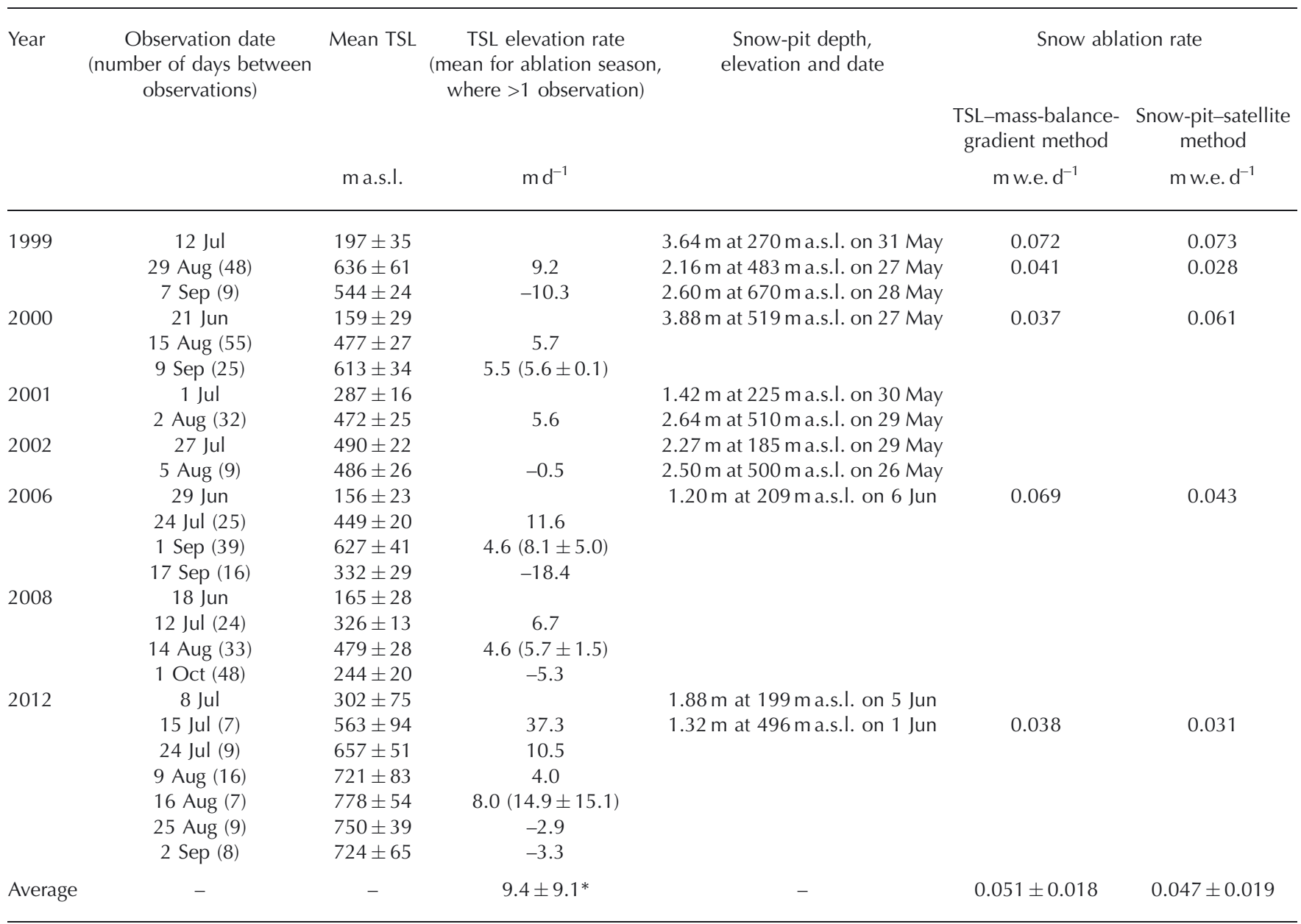

*Mean TSL elevation rate was calculated based on positive rates.

and below, \pm is stated as plus or minus one standard deviation). At the beginning of the accumulation season, negative LCG TSL migration rates occurred within the range -1.6 to $-15.4 \mathrm{~m} \mathrm{~d}^{-1}$ (Table 2), indicating a lowering in the TSL elevation between September and October. The mean TSL migration rate on LCG of $3.8 \mathrm{~m} \mathrm{~d}^{-1}$ compares well with the mean migration rate of $3.7 \mathrm{~m} \mathrm{~d}^{-1}$ on nearby Taku Glacier (Pelto, 2011), a temperate maritime valley glacier located in the Juneau Icefield $\left(671 \mathrm{~km}^{2} ; 58.4^{\circ} \mathrm{N}, 134.1^{\circ} \mathrm{W}\right), \sim 20 \mathrm{~km}$ to the northeast of LCG. The larger area of Taku Glacier allows the use of high temporal resolution Moderate Resolution Imaging Spectroradiometer (MODIS) imagery for accurate TSL identification. This provides additional dates closer to the end of the ablation season, and allows application of the TSL migration rate for well-constrained estimates of the snow ablation rates and the location (elevation) and date of the annual ELA.

For MG the observed positive TSL migration rates varied from $5.6 \pm 0.1 \mathrm{~m} \mathrm{~d}^{-1}$ (for the 2000 ablation season) to $14.9 \pm 15.1 \mathrm{~m} \mathrm{~d}^{-1}$ (2012) (having a migration rate up of to $37.3 \mathrm{~m} \mathrm{~d}^{-1}$ between subsequent satellite observations), with a mean for all ablation periods of $9.4 \pm 9.1 \mathrm{~m} \mathrm{~d}^{-1}$ (Table 3). At the beginning of the MG accumulation season, from the end of August to September/October, TSL migration rates ranged from -0.5 to $-18.4 \mathrm{~m} \mathrm{~d}^{-1}$, illustrating the lowering rate of the TSL (Table 3). The TSL migration rate was used to determine snow ablation rates using both methods: the TSL-massbalance-gradient method and the snow-pit-satellite method (see Section 3). For LCG, based on the TSL-mass-balance method, the snow ablation rates varied from 0.023 to

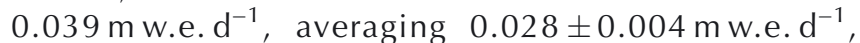
whereas snow ablation rates based on the snow-pit-satellite method varied from 0.025 to $0.038 \mathrm{mw}$ e. $\mathrm{d}^{-1}$, averaging $0.031 \pm 0.004 \mathrm{~m}$ w.e. $\mathrm{d}^{-1}$ (Fig. 3a; Table 2). The JIRP ablation measurements for LCG during the 2004-10 ablation seasons, over a total period of 162 days, yield a mean snow ablation rate of $0.031 \mathrm{mw}$.e. $\mathrm{d}^{-1}$, which is in accordance with calculations: the estimated snow ablation rates for LCG were significantly identical $(97.5 \%$ quartile; based on the null hypothesis). The similarity of the TSL and field snow ablation rates supports the concept that remote-sensing TSL observations (which can be extended over longer time periods and are not simple point measurements), together with field snow-pit observations, offer a useful approach for estimating annual ablation rates, which are important in assessing changes in glacier mass balance in the Juneau Icefield region.

For MG the snow ablation rates showed more variability

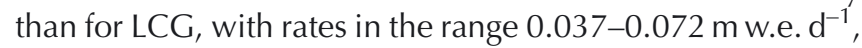
averaging $0.051 \pm 0.018 \mathrm{mw}^{\mathrm{e}} . \mathrm{d}^{-1}$ (based on the TSL-

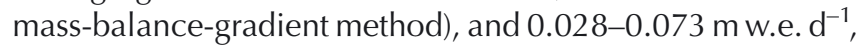
averaging $0.047 \pm 0.019 \mathrm{~m}$ w.e. $\mathrm{d}^{-1}$ (based on the snow-pitsatellite method) (Fig. 3b; Table 3). However, the estimated 
Table 4. Observed and TSL satellite-derived AAR for LCG (1998-2011) and MG (1999-2012)

\begin{tabular}{|c|c|c|c|c|}
\hline \multirow[t]{2}{*}{ Year } & \multicolumn{2}{|c|}{ LCG } & \multicolumn{2}{|c|}{ MG } \\
\hline & $\begin{array}{c}\text { Observed AAR } \\
\text { (WGMS, } 2011 \text { updated)* }\end{array}$ & TSL satellite-derived AAR* & $\begin{array}{l}\text { AAR from mass-balance } \\
\text { observations (Mernild and } \\
\text { others, } 2011 \mathrm{~b} \text { updated })^{\dagger}\end{array}$ & TSL satellite-derived $\mathrm{AAR}^{+}$ \\
\hline
\end{tabular}

\begin{tabular}{|c|c|c|c|c|}
\hline $1997 / 98$ & 0.07 & - & - & - \\
\hline 1998/99 & 0.68 & - & 0.18 & 0.24 \\
\hline $1999 / 2000$ & 0.82 & - & 0.05 & - \\
\hline $2000 / 01$ & 0.77 & - & 0.00 & - \\
\hline 2001/02 & 0.67 & - & 0.41 & - \\
\hline $2002 / 03$ & 0.05 & - & 0.75 & - \\
\hline $2003 / 04$ & 0.59 & 0.28 & 0.05 & - \\
\hline $2004 / 05$ & 0.61 & - & 0.00 & - \\
\hline $2005 / 06$ & 0.68 & 0.47 & 0.18 & 0.38 \\
\hline 2006/07 & 0.72 & 0.63 & 0.00 & - \\
\hline $2007 / 08$ & 0.80 & - & 0.41 & 0.63 \\
\hline 2008/09 & 0.64 & - & 0.18 & - \\
\hline $2009 / 10$ & 0.50 & 0.50 & 0.00 & - \\
\hline 2010/11 & 0.43 & 0.20 & 0.00 & - \\
\hline $2011 / 12$ & - & - & 0.00 & 0.07 \\
\hline Average and std dev. & $0.57 \pm 0.240 .58 \pm 0.12^{\S}$ & $0.42 \pm 0.17^{\S}$ & $0.16 \pm 0.220 .19 \pm 0.17^{\S}$ & $0.33 \pm 0.24^{\S}$ \\
\hline
\end{tabular}

*LCG AAR was estimated based on a fixed area of $11.4 \mathrm{~km}^{2}$ (2001) (Fig. 2a).

The observed MG AAR was calculated based on a fixed area of $17.6 \mathrm{~km}^{2}$.

MG AAR was estimated based on an assumed linearly decreasing area from $17.3 \mathrm{~km}^{2}$ (1999) to 15.9 km² (2011) (Fig. 2b).

${ }^{\S}$ Average and standard deviations were calculated for years where data are available from both glaciers.

snow ablation rates for MG were significantly identical (97.5\% quartile; based on the null hypothesis). At MG no direct field snow ablation measurements have been conducted to validate the estimated snow ablation values, but in future mass-balance model simulations the calculated snow ablation rates have the potential to be compared against simulated ablation rates. Mernild and others (2006) presented simulated daily snow and ice melt rates using the modeling software package SnowModel (Liston and Elder, 2006; Mernild and others, 2010; Liston and Mernild, 2012) for the period 1999-2004, and these simulated rates $\left(0.03-0.04 \mathrm{mw}^{-e} . \mathrm{d}^{-1}\right)$ were on average slightly lower than the estimated snow ablation rates presented in this study (Fig. 3b). A reason for this could be that the TSL-mass-balance-gradient and snow-pit-satellite methods concern the ablation rate of the snowpack (melt, evaporation and sublimation), whereas SnowModel simulations only include surface melt rates from the snowpack and the bare glacier ice (SnowModel simulations forced by mean daily climate data).

The satellite-derived TSL and dates for LCG and MG provide a dataset for estimating the annual ELA and the date of the end of the ablation season. In Figure $4 a$ and $b$, seasonal variations of TSL are shown for LCG $(2004,2006$, 2007, 2010 and 2011) and MG (1999, 2006, 2008 and 2012). A second-order polynomial regression between the day of year (DOY) and TSL on an annual scale indicates that ELA for LCG varies between 1020 ma.s.l. in 2007 and $1170 \mathrm{ma.s.l}$. in 2011, and the ablation seasons ended between DOY 234 (22 August) and DOY 260 (17 September) for the years where satellite-derived TSL observations through and beyond the ablation season were available. These estimated ELA conditions for LCG are in accordance with annual fieldwork observations (Fig. 2a), although ELA is overestimated on average by $\sim 50 \mathrm{~m}$ a.s.l. compared to direct observations; much of this overestimation occurred from 2011, where no TSL observations were available within
15 days of the end of the melt season. For MG, the estimated annual ELA was located between $460 \mathrm{~m}$ a.s.l. (2008) and $780 \mathrm{~m}$ a.s.l. (2012), and the ablation season ended between DOY 227 (15 August) and DOY 230 (18 August). The estimated ELA was significantly identical to MG annual field observations (97.5\% quartile; based on the null hypothesis), although the estimated ELA was on average underestimated by $\sim 90$ m a.s.l. (Fig. 2b), giving reason to believe that the method presented here is useful for ELA estimations at both MG and LCG. For the years 1999, 2006, 2008 and 2012 the MG ablation season ended within 3-4 days in mid-August. At MG the $B_{\text {a }}$ observations are conducted in early/midAugust, which seems to be a good time for capturing the majority of the ablation season (at least for the four years 1999, 2006, 2008 and 2012 as illustrated in Fig. 4b); however, surface melt occurred considerably later in particular years (e.g. until late October in 2010 and late September in 2012).

\section{$A A R$ and $B_{\mathrm{a}}$ reconstruction}

AAR varies greatly from one year to another (Table 4); however, for a period long enough to filter out extremes but shorter than the timescale of adjustment to glacier equilibrium, it gives a measure of the health of the glacier (Cogley and others, 2011). For LCG, observed AAR varied between 0.07 (1998) and 0.82 (2000) for the period 1997/98 to $2011 / 12$, averaging $0.57 \pm 0.24$, while AAR for MG varied between 0.75 (2003) and 0.00 (e.g. 2012) for the period 1998/99 to 2011/12, averaging $0.15 \pm 0.22$ (Table 4). MG experienced $A A R=0$ six times within the last 14 years, including the three most recent years in this study (2010, 2011 and 2012). According to Dyurgerov and others (2009), glaciers and ice caps in equilibrium with the local climate typically have an AAR of $0.5-0.6$, with a global average of $0.579 \pm 0.009$. Pelto (2010) identified that glaciers having a frequent $\mathrm{AAR}=0$ lack a persistent accumulation zone and cannot survive. 

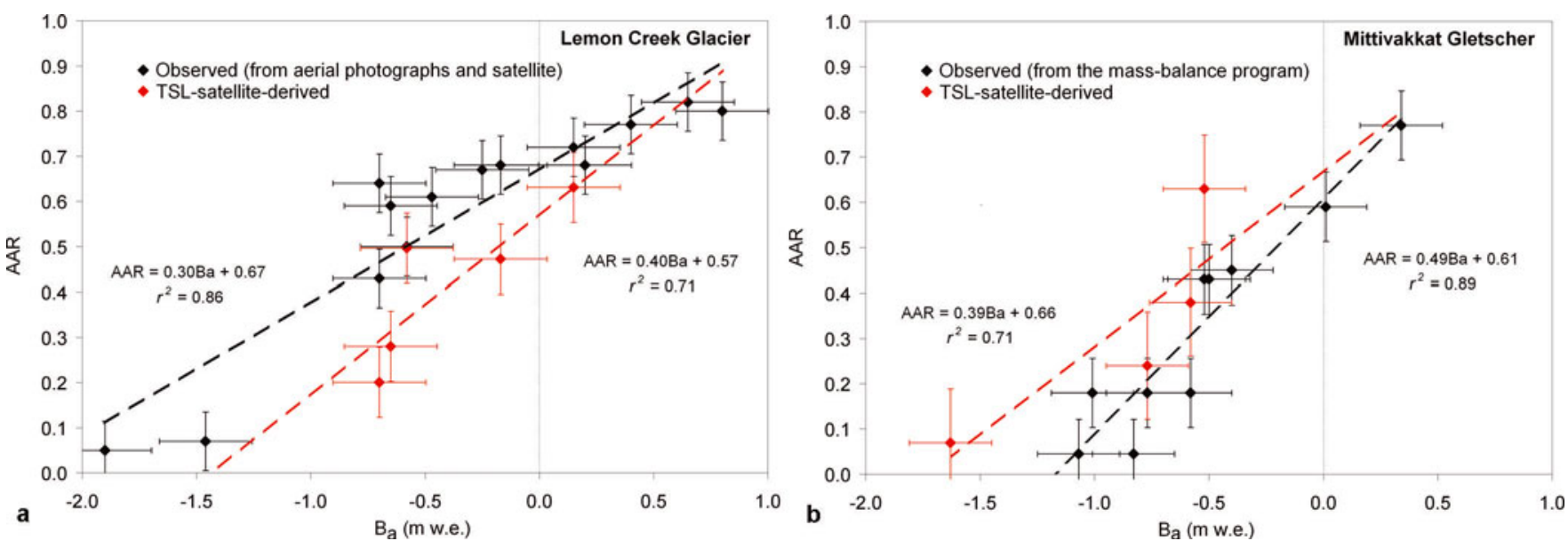

Fig. 5. (a) LCG observed AAR and $B_{\mathrm{a}}$ trend line (dashed black line) from 1997/98 to 2010/11, and TSL satellite-derived AAR and observed $B_{\mathrm{a}}$ trend line (dashed red line) based on data from 2003/04, 2005/06, 2006/07, 2009/10 and 2010/11. Also illustrated are standard errors for each dataset. (b) MG observed AAR and $B_{a}$ trend line (dashed black line) from 1995/96 to 2011/12 (zero values of AAR are excluded from the regression, as AAR and $B_{a}$ are only linearly related when ELA is located within the elevation range of the glacier), and TSL satellitederived AAR and observed $B_{\text {a }}$ trend line (dashed red line) based on data from 1998/99, 2005/06, 2007/08 and 2011/12. Also illustrated are standard errors for each dataset.

In Table 4, annual TSL satellite-derived AAR values are listed for LCG (2004, 2006, 2007, 2010 and 2011) and MG (1999, 2006, 2008 and 2012) and compared against field observations. For LCG the TSL satellite-derived method on average underestimated AAR by $0.16(16 \%)$ compare to observations, and for MG AAR overestimated on average by $0.14(14 \%)$, but since the respective error bars overlap, there is no significant difference. In Figure $5 a$ and b, TSL satellitederived AAR is plotted against $B_{a}$ for LCG and MG. The TSL satellite-derived AAR $B_{a}$ trend lines (red lines) follow observed values and trend lines (black lines). If additional observations are added to the trend lines, $B_{\text {a }}$ can be substituted by the satellite observations, once sufficient data exist to better constrain late-season TSL behavior and hence annual AAR determination. Based on the LCG satellitederived $A A R$ and $\mathrm{AAR}_{0}$ conditions (Fig. 5a), expected changes in the LCG area and volume can be derived from

$$
\alpha_{\mathrm{r}}=\mathrm{AAR} / \mathrm{AAR}_{0}
$$

the ratio of the current $A A R$ to its equilibrium value. The fractional changes in area $\left(p_{\mathrm{s}}\right)$ and in volume $\left(p_{\mathrm{v}}\right)$ are calculated from

$$
\begin{aligned}
& p_{\mathrm{s}}=\alpha_{\mathrm{r}}-1 \\
& p_{\mathrm{v}}=\alpha_{\mathrm{r}}^{\gamma}-1
\end{aligned}
$$

where $\gamma=1.36$ for valley glaciers, derived empirically and from theory (Bahr and others, 2009). Based on the LCG trend between the TSL satellite-derived AAR and $B_{\mathrm{a}}$, LCG has an estimated $A A R_{0}$ of 0.57 that is comparable to the observed $\mathrm{AAR}_{0}$ value of 0.67 (Fig. 5a). Dyurgerov and others (2009) computed $\mathrm{AAR}_{0}$ for 86 glaciers and ice caps by using linear regression between $A A R$ and $B_{\mathrm{a}}$, showing an average value of $0.58 \pm 0.01$. The resulting LCG AAR $(0.42$; Table 4$)$ and $\mathrm{AAR}_{0}$ values $(0.57$; Fig. 5a) (based on the TSL satellitederived AAR relationship to $B_{\mathrm{a}}$ ) indicate that LCG will lose $26 \pm 3 \%$ of its present area and $34 \pm 3 \%$ of its volume typically over several decades or longer if current climate conditions in the region of LCG persist. Based on observed AAR (0.57; Table 4) and $\mathrm{AAR}_{0}$ (0.67; Fig. 5a), LCG will respectively lose $15 \pm 1 \%$ and $20 \pm 2 \%$. Similar area and volume fraction calculations were conducted for MG, indicating that MG based on the TSL satellite-derived AAR (0.33; Table 4) and $\mathrm{AAR}_{0}$ (0.66; Fig. 5b) will lose about $50 \pm 6 \%$ of its present area and $61 \pm 5 \%$ of its volume if current climate conditions in southeast Greenland persist. MG is significantly out of balance with climate, and far below the global AAR mean, and will likely lose a significant amount of its current area and volume even in the absence of further climate changes. Based on $\alpha_{r}$ calculations from observations in Mernild and others (2011a) $\left(A A R=0.16\right.$ (Table 4) and $A_{A R}=0.61$ (Fig. 5b)), MG will lose $74 \pm 8 \%$ of its current area and $84 \pm 7 \%$ of its volume over several decades or longer if current climate conditions persist. For both glaciers the satellite-estimated fractional areal and volume losses seem to point out the extent to which the glaciers are out of balance with presentday climate observations.

An expansion of the study by adding satellite-derived annual glacier conditions, i.e. ELA, AAR and $B_{\mathrm{a}}$, is desirable to better quantify the presented relationships, to increase accuracy and further validate the findings at LCG and MG. Also, so-called 'transient' area-averaged mass balances can be computed and related to concurrent transient ELA and AAR values; this method assumes that the relationship between transient values of mass balance and ELA and AAR in the course of one season is identical to the relationship between $B_{\mathrm{a}}$ and ELA and AAR at the end of the mass-balance year over many years (Hock and others, 2007).

\section{CONCLUSIONS}

Snow ablation rates determined from observations of TSL migration by Landsat imagery and the balance gradient (from the TSL-mass-balance-gradient method) agree significantly with field measurements of snow ablation using stakes and snowpack loss identified directly at snow-pit locations from TSL variation (from the snow-pit-satellite method), varying on average in the ranges 0.028-0.031 and 0.047-0.051 m w.e. $\mathrm{d}^{-1}$ for LCG and MG, respectively. This supports the utility of using TSL observations to estimate ELA 
and AAR conditions on LCG and MG, but also at seasonal scale for LCG and MG if a relationship between transient mass balance, ELA and AAR values occurs. It is likely this will be useful for assessing nearby glaciers where field data are lacking but which share a similar rate of TSL rise, as this would indicate a similar balance gradient, which is not unusual for glaciers in the same climate setting (Braithwaite and Raper, 2007). For LCG the estimated ELA varied between 1020 and $1170 \mathrm{~m}$ a.s.l., and for MG between 480 and $780 \mathrm{~m}$ a.s.l. For both glaciers the estimated ELA and AAR were in accordance with annual fieldwork observations, indicating that the method presented here is useful for ELA and AAR estimations, but also for estimating out-of-balance conditions, where MG is significantly out of balance with present-day climate, and LCG less so.

\section{ACKNOWLEDGEMENTS}

This work was supported by the Earth System Modeling program and by the Scientific Discovery for Advanced Computing (SciDAC) program within the US Department of Energy's Office of Science and by a Los Alamos National Laboratory (LANL) Director's Fellowship. LANL is operated under the auspices of the National Nuclear Security Administration of the US Department of Energy under contract No. DE-AC52-06NA25396, and partly from the European Community's Seventh Framework Programme under grant agreement No. 262693. The LCG mass-balance data would not exist without the leadership of JIRP directors Maynard Miller, Jay Fleischer and Jeff Kavanaugh. We also thank the May/June 2012 Mittivakkat Gletscher field crew for collecting winter balance and snow-pit data. S.H.M., J.K.M. and M.P. compiled the dataset and analyzed the data, and S.H.M. and M.P. wrote the manuscript. J.C.Y., J.K.M., N.T.K. and E.H. contributed to the discussion of results and writing of the text.

\section{REFERENCES}

Bahr DB, Dyurgerov M and Meier MF (2009) Sea-level rise from glaciers and ice caps: a lower bound. Geophys. Res. Lett., 36(3), L03501 (doi: 10.1029/2008GL036309)

Born EW and Böcher J (2001) The ecology of Greenland. Ministry of Environment and Natural Resources, Greenland, Nuuk

Braithwaite RJ and Raper SCB (2007) Glaciological conditions in seven contrasting regions estimated with the degreeday model. Ann. Glaciol., 46, 297-302 (doi: 10.3189/ 172756407782871206)

Cogley JG and 10 others (2011) Glossary of glacier mass balance and related terms. (IHP-VII Technical Documents in Hydrology 86) UNESCO-International Hydrological Programme, Paris

Dyurgerov M (1996) Substitution of long-term mass balance data by measurements of one summer. Z. Gletscherkd. Glazialgeol., 32, 177-184

Dyurgerov M, Meier MF and Bahr DB (2009) A new index of glacier area change: a tool for glacier monitoring. J. Glaciol., 55(192), 710-716 (doi: 10.3189/002214309789471030)

Hall DK, Chang ATC, Foster JL, Benson CS and Kovalick WM (1989) Comparison of in situ and Landsat derived reflectance of Alaskan glaciers. Remote Sens. Environ., 28, 23-31 (doi: 10.1016/0034-4257(89)90102-8)

Hanna E, Mernild SH, Cappelen J and Steffen K (2012) Recent warming in Greenland in a long-term instrumental (1881-2012) climatic context: I. Evaluation of surface air temperature records. Environ. Res. Lett., 7(4), 045404 (doi: 10.1088/1748-9326/7/4/ 045404)
Hock R, Kootstraa D-S and Reijmer C (2007) Deriving glacier mass balance from accumulation area ratio on Storglaciären, Sweden. IAHS Publ. 318 (Symposium at Foz do Iguaçu 2005 - Glacier Mass Balance Changes and Meltwater Discharge), 163-170

Knudsen NT and Hasholt B (1999) Radio-echo sounding at the Mittivakkat Gletscher, southeast Greenland. Arct. Antarct. Alp. Res., 31(3), 321-328

Knudsen NT and Hasholt B (2008) Mass balance observations at Mittivakkat Gletscher, Southeast Greenland 1995-2006. Geogr. Tidsskr., 108(1), 111-120

Knudsen NT, Nønberg P, Yde JC, Hasholt B and Heinemeier J (2008) Recent marginal changes of the Mittivakkat Glacier, Southeast Greenland and the discovery of remains of reindeer (Rangifer tarandus), polar bear (Ursus maritimus) and peaty material. Geogr. Tidsskr., 108(1), 137-142

Liston GE and Elder K (2006) A distributed snow-evolution modeling system (SnowModel). J. Hydromet., 7(6), 1259-1276 (doi: 10.1175/JHM548.1)

Liston GE and Mernild SH (2012) Greenland freshwater runoff. Part I: a runoff routing model for glaciated and nonglaciated landscapes (HydroFlow). J. Climate, 25(17), 5997-6014 (doi: 10.1175/JCLI-D-11-00591.1)

Marcus MG, Chambers FB, Miller MM and Lang M (1995) Recent trends in the Lemon Creek Glacier, Alaska. Phys. Geogr., 16(2), 150-161

Mernild SH and Liston GE (2010) The influence of air temperature inversions on snow melt and glacier surface mass-balance simulations, Ammassalik Island, Southeast Greenland. J. Appl. Meteorol. Climatol., 49(1), 47-67 (doi: 10.1175/ 2009JAMC2065.1)

Mernild SH, Liston GE, Hasholt B and Knudsen NT (2006) Snow distribution and melt modeling for Mittivakkat Glacier, Ammassalik Island, Southeast Greenland. J. Hydromet., 7(4), 808-824 (doi: 10.1175/JHM522.1)

Mernild SH, Hansen BU, Jakobsen BH and Hasholt B (2008) Climatic conditions at the Mittivakkat Glacier catchment (1994-2006), Ammassalik Island, SE Greenland, and in a 109-year perspective (1898-2006). Geogr. Tidsskr., 108(1), $51-72$

Mernild SH, Liston GE, Steffen K and Chylek P (2010) Meltwater flux and runoff modeling in the ablation area of Jakobshavn Isbræ, West Greenland. J. Glaciol., 56(195), 20-32 (doi: 10.3189/002214310791190794)

Mernild SH and 6 others (2011a) Increasing mass loss from Greenland's Mittivakkat Gletscher. Cryosphere, 5(2), 341-348 (doi: 10.5194/tc-5-341-2011)

Mernild SH, Knudsen NT and Hanna E (2011b) Mittivakkat Gletscher, SE Greenland. In Richter-Menge J, Jeffries $\mathrm{MO}$ and Overland JE eds. Actic Report Card. (NOAA Report 2011) National Oceanic and Atmospheric Administration, Washington, DC http://www.arctic.noaa.gov/report11/

Mernild SH, Malmros JK, Yde JC and Knudsen NT (2012) Multidecadal marine- and land-terminating glacier recession in the Ammassalik region, southeast Greenland. Cryosphere, 6(3), 625-639 (doi: 10.5194/tc-6-625-2012)

Mernild SH and 7 others (2013) Volume and velocity changes at Mittivakkat Gletscher, southeast Greenland. J. Glaciol., 59(216), 660-670

Miller MM and Pelto MS (1999) Mass balance measurements on the Lemon Creek Glacier, Juneau Icefield, Alaska 1953-1998. Geogr. Ann. A, 81(4), 671-681

Østrem G (1975) ERTS data in glaciology - an effort to monitor glacier mass balance from satellite imagery. J. Glaciol., 15(73), 403-415

Pelto MS (2010) Forecasting temperate alpine glacier survival from accumulation zone observations. Cryosphere, 4(1), 67-75 (doi: 10.5194/tc-4-67-2010)

Pelto M (2011) Utility of late summer transient snowline migration rate on Taku Glacier, Alaska. Cryosphere, 5(4), 1127-1133 (doi: 10.5194/tc-5-1127-2011) 
Pelto MS and Miller MM (1990) Mass balance of the Taku Glacier, Alaska from 1946 to 1986. Northwest Sci., 64(3), 121-130

Sapiano JJ, Harrison WD and Echelmeyer KA (1998) Elevation, volume and terminus changes of nine glaciers in North America. J. Glaciol., 44(146), 119-135

Tachikawa T and 12 others (ASTER GDEM Validation Team) (2011) ASTER Global Digital Elevation Model Version 2 - summary of validation results, NASA Land Processes. NASA Distributed
Active Archive Center, Joint Japan-US ASTER Science Team, http://www.jspacesystems.or.jp/ersdac/GDEM/ver2Validation/ Summary_GDEM2_validation_report_final.pdf

World Glacier Monitoring Service (WGMS) (2011) Glacier Mass Balance Bulletin No. 11 (2008-2009), ed. Zemp M, Nussbaumer SU, Gärtner-Roer I, Hoelzle M, Paul F and Haeberli W. ICSU(WDS)/IUGG(IACS)/UNEP/UNESCO/WMO, World Glacier Monitoring Service, Zürich

MS received 17 November 2012 and accepted in revised form 12 April 2013 